\title{
Problem analysis and systematic approach in teaching discipline "Chemistry" for the integral scientific and professional training of engineers
}

\author{
A. V. Pidgornyy, T. I. Duda*, O. K. Nahorna \\ National Technical University of Ukraine "Igor Sikorsky Kyiv Polytechnic Institute", Kyiv, Ukraine \\ *Corresponding author: E-mail: tetiana.duda@gmail.com
}

Paper received 06.12.17; Revised 12.12.17; Accepted for publication 15.12.17.

https://doi.org/10.31174/SEND-NT2017-148V16-03

\begin{abstract}
The paper analyzes the problems of low efficiency of students' educational work over the discipline "Chemistry" and considers the principles of modernizing educational activities and the task of engineering education reforming. The relationship of fundamentalism of graduates education with requirements of high-tech labor market is shown. The role of interdisciplinary connections in the training of highly skilled specialists for new branches of science and technology, which is formed on the basis of a combination of achievements in natural sciences: chemistry, physics, mathematics, biology, is considered.
\end{abstract}

Keywords: chemistry, engineering skills, professional competencies.

Introduction. Improving the quality of education, achieving its level of conformity with the actual and prospective needs of society, state and personality is a priority task of educational policy of Ukraine at the present stage. Higher education in Ukraine over the past 10 years has been implementing significant steps for integration into the European educational space. National technical university of Ukraine "Igor Sikorsky Kyiv Politechnic Institute", as one of the leading technical universities in Ukraine, is working hard to implement an effective system of quality management of future specialists training for the country's economy. One of the main tasks of the higher educational institution in accordance with the new realities is the formation of such joint educational and scientific environments in which the educational component would fill the scientific sphere, and a high-tech labor market would be enriched by talented young people from whom future scientists, production and business managers will grow.

Literature review. Modernization of the national education system should be based on the continuous development of the educational system. In the same time, the main task of educational policy is to provide modern education quality based on its fundamental and compliance with relevant provisions of the documents relating to changes in education for sustainable development [1,2].

In this case, the modernization of educational activities should be carried out in accordance with the following principles:

- the unity of the educational space, the parity of education and training, the integration of science and education, academic freedom;

- a combination of connection between education, research and business;

- improving the quality of education through its internationalization;

- practical orientation of university courses to the requirements of labor markets;

- unity and consistency of education levels - "education through life".

Thus, the main task of reforming education is the creation of conditions and the graduation of specialists with fundamental natural science training, original thinking, ability to work in a multicultural environment, capability of providing innovative development of society and business.

The transition of the higher education system of Ukraine to the new educational standards has changed the purpose of the training of graduates of higher educational institutions (HEIs). Currently, the goal of training is the formation of a certain set of general cultural and professional competencies of students. The result of the university education is the competence of its graduates (possession of a list of specified competencies). Individual competence is a complex integral object, which is a dynamic combination of knowledge, skills and personality traits of the subject of educational activity. Formation of the competence of a specialist and the preservation of the disciplinary organization of the educational process are the consequences of a holistic assimilation of the personality of a particular educational branch [3].

According to the results of analytical forecasts of the leading scientific centers of the world (Oxford University, International Council for Science), the most demanded in the labor market will be experts in the field of alternative energy, heat engineering, energy conservation, chemistry, biotechnology, pharmacy, medical engineering, specialists in the field of new materials and nanotechnologies, nanoelectronics, environmental protection, aerospace technology.

However, during the last decades, the issue of the prestige of engineering professions is not sufficiently discussed. Educational priorities have recently focused on issues of general humanitarian problems (history, philosophy, political science, journalism) and on issues of economics, finance, banking, trade, and management and marketing issues. And the issue of the chemical component of engineering education was not considered at all.

Goals. The aim of this study is to identify the causes that lead to poor performance of students on educational discipline "Chemistry" and to develop areas of modernization of educational activities to improve the quality of engineering education.

Methods. The study analyzes the data of the studies of students of Instrumentation Engineering, Heat and Power Engineering, Biomedical Engineering faculties, faculty of 
Aerospace Systems of the National Technical University of Ukraine "Igor Sikorsky Kyiv Polytechnic Institute" on the discipline "Chemistry" on the $1^{\text {st }}$ course of studies at the university. The study covered about 1,200 students in three years.

The official data of the Ministry of Education and Science of Ukraine on the results of the testing of secondary school graduates from the level of mastering the school curriculum was analyzed.

We used the results of evaluation of the entrance level of knowledge of students of the 1st course of engineering specialties. Five teachers of the Department of General and Inorganic Chemistry did the evaluation.

The data of employers' feedback on the quality of NTUU "Igor Sikorsky KPI" graduates, which was taken by the Ukrainian non-governmental social organization "Socio+", was analyzed.

Results and discussion. In accordance with the "Law on Higher Education", implementation of the mechanism of sustainable development of the Ukrainian system of technical education becomes urgent. The main and determining factor in implementing such an approach is to ensure the quality of education based on preserving its fundamental and educational relevance to the actual and future needs of the individual, society and the state.

Training of specialists in three cycles (Bachelor - Master - PhD) leading Ukrainian higher educational establishments carry out by optimized curricula, the filling of which by educational disciplines is due to the developed conceptual, methodological foundations of a new generation of industry standards of higher education. These industry standards are based on a competent approach, taking into account the trends in the nature of work and the requirements for the competence of specialists and the world practice of the formation of educational programs (nomenclature, structure, content) while preserving the best traditions of Ukrainian education (fundamental, practical orientation, etc.).

At the same time, work on modernization is carried out taking into account the following basic principles of educational activity: unity of educational space; parity of education; integration of education and science; academic freedom; unity and consistency of education levels - "education during the life"; balance of interests of the main participants in the educational process - students, teachers, employers and founders; openness (transparency) of education to society. Therefore, the main task of the reform of engineering education is the creation of conditions and the graduation of specialists who have independent critical creative thinking capable of professional growth and professional mobility in the conditions of informatization and internationalization of society and the development of science-intensive technologies capable of solving complex problems of innovative development.

In modern realities, learning is a process that forms a personality. Getting the first higher education gives the student the opportunity to combine the desire to become a specialist with what he wants to learn and how this knowledge is applied. Schematically, the requirements for the content of training are presented in Figure 1 [5]. Requirements to the educational process in terms of the quality of training engineers provided by reformatting curricula in accordance with educational and professional standards. Such training programs should take into account the requirements of employers in relation to the sectoral engineering training of specialists demanded today by the Ukrainian economy and, at the same time, provide the fundamental and scientific training.

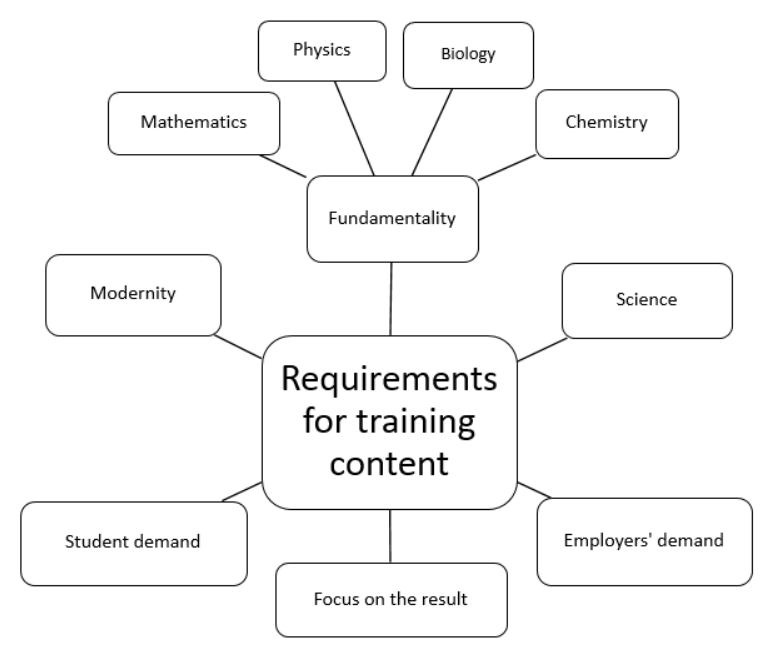

Figure 1. Schematic representation of the requirements for the content of training

During its existence, chemistry always helped and continues to help people with its practical activities. Without chemistry it is impossible to develop a fuel and energy complex, metallurgy, transport, electronics, communication, construction, sphere of life etc. First of all, it means, formation of a sufficient level of chemical culture of future engineers. Each specialist, be it a device engineer, machine builder, heat engineer, as well as a specialist in the field of biomedical engineering, microelectronics, should at least have some knowledge about the chemical components of their activities that contribute to its intensification or at least rationalize the results of work.

A characteristic feature of modern scientific research is to eliminate the distinction between conventional research. On the contrary, when solving problems in the sphere of material production it is necessary, while describing the processes and assessing the properties of structural materials, to apply physical views on the nature of phenomena in combination with the fundamental principles of chemical knowledge, and to be able to ensure compliance with environmental requirements in their implementation. It is also clear that the description of the physical and chemical processes carried out during the operation of technical devices or in the work of closed production cycles requires an engineer of a sufficiently developed level of chemical and mathematical knowledge necessary for analyzing the stages of the investigated processes, developing practical recommendations for solving their optimization problems. The solution of the tasks of disciplines of specialized training is possible only with the wide application of methods and principles of mathematical modeling, physical methods of research, while involving the system of views of modern chemical science, acquired by the student during the first year of study [4].

Taking into account the above, it is clear that the indisputable fact is that the fruitful activity of future engineers in various fields of industry and science is impossible 
without mastering the system of fundamental chemical knowledge.

However, ensuring the qualitative training of engineers within the framework of technical training programs is greatly complicated by the growing gap between the level of training of graduates of Ukrainian schools and the requirements of higher educational establishments. So, after the introduction of the system of extramural education, more than $60 \%$ of graduates of schools with different abilities to study, often with unclear motivation and un- formed views on their future, are enrolled for studying for the first year of universities.

The level of knowledge of entrants from natural sciences is far from the modern requirements due to the decrease of the quality of school textbooks, the lack of interest of young people in the study of exact sciences and engineering professions. According to the results of entrance examinations in natural sciences, almost half of the first-year students have knowledge at a level below the mediocre [5].

Table 1. Comparison of average marks of students' school certificates and average marks of entrance control at the university from the discipline "Chemistry"

\begin{tabular}{|l|c|c|c|c|c|c|}
\hline \multicolumn{1}{|c|}{ Year } & \multicolumn{2}{c|}{$\mathbf{2 0 1 5}$} & \multicolumn{2}{c|}{$\mathbf{2 0 1 6}$} & \multicolumn{2}{c|}{$\mathbf{2 0 1 7}$} \\
\hline Average score / maximum score & score & index & score & index & score & index \\
\hline According to a school certificate & $8.1 / 12$ & 0.675 & $7.3 / 12$ & 0.61 & $7.2 / 12$ & 0.60 \\
\hline The results of entrance control & $2.4 / 5$ & 0.48 & $2.2 / 5$ & 0.44 & $2.1 / 5$ & 0.42 \\
\hline
\end{tabular}

The analysis of the quality of the training success (based on the results of two exam sessions) among the freshmen of the NTUU "Igor Sikorsky Kyiv Polytechnic Institute" during the last three academic years (20142016) shows that the preparation for mathematics exam with a mark of "excellent" (A) and "good" (B, C) had only $13.6 \%$ of students, while $62 \%$ of students got low educational results (marks D, E). The presence of such a large proportion of students with a low level of mathematical preparation largely explains the deterioration of the quality of training in credit modules of related disciplines, especially in physics and chemistry [6].

From the discipline "Chemistry" the number of students with the highest score $(\mathrm{A}, \mathrm{B})$ is up to $10 \%$. At the same time, the number of students with a lower level of knowledge (D, E) increased by $55 \%$.

Unfortunately, approximately $25 \%$ of students were unable to successfully master the necessary knowledge for final semester control simultaneously with several basic disciplines (higher mathematics, physics, computer science, engineering graphics, etc.). The poor performance of this group of students is due to the low level of interest in gaining knowledge, uncertainty in their abilities and inadequate development of skills of independent work and low basic level laid down in secondary school.

The main problems that determine the low effectiveness of the students' work at the first year of studies are as follows. Most students not placed in good faith to implement the planned scope of tasks of independent work (according to modern syllabus credit modules to $50 \%$ of loans provided training courses for extracurricular selfstudy). It is quite clear that in the first months of study, students have not yet adapted to fruitful independent work, which ensures the achievement of a high own learning result. Also, for most students, the typical drawbacks are: poorly formed skills of the use of educationalmethodical literature, electronic sources of information; insufficient ability to plan free time; rooted, from the time of studying at the secondary school, the habit of cheating; inability to motivate to answer questions that require logical thinking; lack of skills in creative assimilation of theoretical material and inability to find a solution to practical individual problems using a complex of knowledge of natural sciences; inadequate interest in learning, including due to the uncertainty about future job placement in the industry in accordance with the received professional qualification.

At the same time, in the technical universities of Ukraine there is an ungrounded tendency towards the process of reducing academic hours for studying the disciplines of the natural sciences cycle, including chemistry, in the curriculum of bachelor's training in technical areas.

In order to preserve the appropriate level of knowledge requirements and establish a solid basic training necessary for successful training in next semesters, lecturers of university make additional efforts to carry out numerical consultations that are necessary to enhance the thinking of freshmen students, to form an understanding of the importance and need for a conscious study of the discipline, control of students' performance of independent tasks. As a result, first-year students on the basis of the ranking system of assessment achieve good results in the second part of the semester, and the index of their implementation of the curriculum is almost $74 \%$.

Thus, the experience of introducing corrective principles of organization of the educational process in Ukrainian technical universities in the context of the Bologna agreements in recent years enables to obtain achievements in the system of organization of qualitative training of engineers, but, at the same time, it is necessary to focus the activities of teachers on the management of such processes as:

- acquisition of new knowledge through the development of students' logical thinking;

- formation of the students' ability to independently solve specific practical problems, the ability to find optimal methods for solving problems;

- development of the ability to analyze in detail the results of research and the ability to obtain an acceptable engineering solution based on the application of known algorithms of the solution, the principles of analogy.

Conclusions. It is established that the level of knowledge on the discipline "Chemistry" of high school graduates in Ukraine is too low and cannot serve as a basis for studying the university course. It is necessary to change the content and quality of the school curriculum or to create classes with intensive training in natural sciences.

The main problems, which determine the low efficiency of educational work of students of the first year, are as follows: insufficient motivation of students in performing 
of independent work outside the classroom, organizational and motivational inappropriateness to fruitful independent work, poorly formed skills of the use of educational-methodical literature, electronic sources of information; the habit of cheating; inability to motivate to answer questions that require logical thinking; lack of skills in creative assimilation of theoretical material and inability to find a solution to practical individual problems using a complex of knowledge of natural sciences; inadequate interest in learning, including due to the uncertainty about future job placement in the industry in accordance with the received professional qualification.

The tendency towards the process of reducing academic hours for the study of natural sciences, as well as the abolition of semester examinations in chemistry at most faculties of technical universities, and at some of them in general, the exclusion of the discipline "Chemistry" from the curriculum, does not contribute to the achievement of the modern scientific level of the fundamental component of the general engineering and special profile training.

The implementation of the modern paradigm of acquiring and realizing knowledge through the hierarchical helix "education - science - innovations - new knowledge in education" can only be provided on the basis of perfect training in fundamental natural sciences, especially in physics and chemistry.

\section{REFERENCES}

1. Budapest-Viena Declaration on the European Higher Education Area.- URL

http://www.ond.vlaanderen.be/hogeronderwijs/bologna/2010 _conference

2. 2020 A strategy for smart, sustainable and inclusive growth. Communication of the Europian Commission 3.32010 № 52010DC2020 [Electronic resopurce]. Retrieved from: http://Eur-lex.europa.eu/legalcontent/EN/TXT/?uri=celex\%3A52010DC2020

3. Intehratsiia $\mathrm{v}$ yevropeiskyi osvitnnii prostir: zdobutky, prroblemy, perspektyvy : monohrafia /[F.H. Vashchuk ta in.] ; za zah. red. d-ra tekhn. nauk, prof. F.H. Vashchuka; Zakarpat. Derzh. Un-t, Navch.-nauk. in-t yevrointehrats. doslidzh., Navch.-nauk. in-tinform. Tekhnolohi. - Uzhorod :[ZakDU],2011.- 559 s. (in Ukraine).
4. Pidgornyy A.V., Nazarova T.M. Fundamentalna pidgotovka bakalavriv u konteksti zabezpechennya rozvytku naukovodoslidnetskoi strategii ingenernoi osvity // Vyscha osvita Ukrainy u konteksti integratsii do evropeyskogo osvitnyogo prostoru,- Dodatok 1 do №5, T. (56). - 2014. - Kyiv; Ukraine, P. 345-351 (in Ukraine)

5. Pidgornyy A.V., Nazarova T.M. A Look at the issues of training specialists of higher engineering education//European Humanities Studies.Education and Trainining- 2016.-T.II.-S.141-151. Slupsk (in Poland).

6. Yakymenko Yu. I. Stvorennya konkurentnospromozhnoi osvity - vymoga chasu // Kyivskyy politechnik. - №12 (3151). - 2016 (in Ukraine).

Анализ проблем и системный подход в преподавании дисциплины «Химия» для достижения целостного научнопрофессионального обучения инженеров

\section{А. В. Подгорный, Т. И. Дуда, О. К. Нагорная}

Аннотация. В работе анализируются проблемы низкой эффективности учебной работы студентов над дисциплиной «Химия» и рассматриваются принципы и задачи модернизации образовательной деятельности. Показана взаимосвязь фундаментальности инженерного образования с требованиями высокотехнологичного рынка труда. Рассмотрены роль междисциплинарных связей, качество учебных планов и программ, а также и особенности педагогических подходов в подготовке высококвалифицированных инженеров для новых отраслей науки и техники, которые сформированы на основе сочетания достижений естественных наук: химии, физики, математики, биологии.

Ключевые слова: химия, инженерные навыки, профессиональные компетенции. 